\title{
IMPLEMENTASI AKTIVITAS BIAYA BERDASARKAN PERHITUNGAN ACTIVITY BASED COSTING (ABC) UNTUK MENENTUKAN IURAN PENGELOLA (IPL) APARTEMEN (STUDI KASUS PADA APARTEMEN WOODLAND PARK RESIDENCE TOWER MATOA)
}

\author{
Ghina Saussan ${ }^{1}$, Lely Dahlia ${ }^{2 *}$ \\ 1,2 Fakultas Ekonomi dan Bisnis, Universitas Trilogi \\ *e-mail: gsaussan@gmail.com
}

\author{
DiPublikasi: 01/07/2021 \\ https://doi.org/10.22225/kr.13.1.2021.86-95
}

\begin{abstract}
This study aims to design a method of allocating costs on Activity Based Costing (ABC) method to identified business processes and activities in the Woodland Park Residence Tower Matoa apartment, to know the amount of service charge for 3 types of occupancy and to know there is a difference between the calculations using the the ABC method, traditional methods and applicable rates. The calculation of costs using ABC method produces results, service charge for the studio type of IDR 262,437 per month, $1+1$ BR IDR 392,382 per month and type 2 BR IDR 549,450 per month. Meanwhile, if calculated using the traditional method, service charge for the studio type is IDR 257,478 per month. Then for type $1+1$ BR the service charge is IDR 384,912 per month. Finally, type 2 BR service charge is IDR 538,990 per month. If the apartment uses the applicable rates, then service charge the studio type IDR 516,200, the type $1+1$ BR per month is IDR 791,600 and type 2 BR per month is IDR 1,112,000. Thus there has been an overcost in the studio type of IDR 253,763. For service charge type $1+1$ BR, there was an overcost of IDR 399,218. For service charge type 2 BR, there is an overcost of IDR 562,550.

Keywords: Apartment Service Charge; Apartment; Activity Based Costing (ABC); Traditional Costing

Abstrak

Penelitian ini bertujuan untuk merancang metode pengalokasian biaya berbasis Activity Based Costing (ABC) berdasarkan proses bisnis dan aktivitas teridentifikasi di Pengelola apartemen Woodland Park Residence Tower Matoa, mengetahui besarnya Iuran Pengelola (IPL) pada 3 tipe hunian serta mengetahui apakah ada perbedaan antara perhitungan dengan menggunakan metode ABC, metode tradisional dan tarif yang berlaku. Penelitian ini dilakukan di apartemen Woodland Park Residence Kalibata Raya. Perhitungan biaya menggunakan metode ABC memperoleh hasil, yaitu Iuran Pengelola (IPL) per bulan tipe studio sebesar Rp 262.437 per bulan, $1+1$ BR sebesar Rp 392.382 per bulan dan tipe 2 BR sebesar Rp 549.450 per bulan. Sedangkan bila dihitung dengan metode tradisional maka Iuran Pengelola (IPL) per bulan tipe hunian studio sebesar Rp 257.478 per bulan. Kemudian pada tipe $1+1$ BR sebesar Rp 384.912 per bulan. Terakhir pada tipe hunian 2 BR sebesar Rp 538.990 per bulan. Jika apartemen menggunakan IPL yang berlaku saat ini, yaitu tipe studio sebesar Rp 516.200, sedangkan tipe $1+1$ BR per bulan sebesar Rp 791.600 dan tipe 2 BR per bulan sebesar Rp 1.112.000. Dengan demikian telah terjadi overcosted pada tipe studio sebesar Rp 253.763. Untuk Iuran pengelola (IPL) tipe $1+1$ BR terjadi overcost sebesar Rp 399.218. Untuk Iuran pengelola (IPL) tipe 2 BR terjadi overcost sebesar Rp 562.550.
\end{abstract}

Kata Kunci : Iuran Pengelola Apartemen; Apartemen; Activity Based Costing (ABC); Traditional Costing

\section{PENDAHULUAN}

Bertambahnya jumlah penduduk yang mengharapkan tempat tinggal yang layak. Namun terdapat keterbatasan tanah yang membuat pihak swasta merencanakan konsep pembangunan apartemen yang dihuni secara bersama-sama. Setelah pembangunan apartemen selesai pelaku bisnis apartemen biasanya mengalami kesulitan

dalam menentukan Iuran Pengelola (IPL) apartemen yang tepat. Hal ini dikarenakan dalam menentukan besarnya IPL pihak apartemen harus menghitung Ketepatan dan keakuratan aktivitas biaya terlebih dahulu.

Perkembangan perhitungan aktivitas biaya di 
beberapa apartemen saat ini masih dihitung berdasarkan seluruh biaya yang terjadi baik biaya pelayanan untuk penghuni maupun yang bukan pelayanan untuk penghuni, kemudian dimasukkan sebagai pertimbangan besaran IPL. Apartemen yang dimaksud salah satunya adalah Apartemen Woodland Park Residence Tower Matoa yang beralamat di jalan Kalibata Raya. Sehingga peneliti

\section{TINJAUAN PUSTAKA \\ Biaya}

Biaya menurut (Mulyadi, 2015) adalah "pengorbanan sumber ekonomis yang diukur dalam satuan uang, baik biaya yang telah terjadi, sedang terjadi maupun yang kemungkinan akan terjadi untuk tujuan tertentu". Biaya menurut (Hansen, D. R., Mowen, M.M., \& Guan, 2015) adalah "kas atau nilai setara kas yang dikorbankan untuk mendapatkan barang atau jasa yang diharapkan memberi manfaat saat ini atau di masa depan bagi organisasi". Biaya menurut (Horngren, Charles T., 2015) adalah "sumber daya yang dikorbankan untuk mencapai tujuan tertentu. Biaya tersebut seperti, biaya tenaga kerja, biaya iklan dan sebagainya". Biaya biasanya diukur sebagai jumlah uang yang harus dibayar untuk mendapatkan barang atau jasa. Biaya menurut Supriyono (2011) adalah "harga perolehan yang dikorbankan atau digunakan dalam rangka memperoleh penghasilan (revenue) yang akan dipakai sebagai pengurang penghasilan".

Berdasarkan definisi di atas dapat disimpulkan bahwa biaya adalah suatu pengorbanan yang dilakukan oleh entitas yang bertujuan untuk mendapatkan manfaat yang lebih dari aktivitas yang dilakukan. Salah satu hal dalam pengelolaan berupa barang atau jasa, dimana besaran biaya dapat menentukan jenis pelayanan serta kualitas pelayanan yang akan diberikan. Selain itu, biaya merupakan nilai pengorbanan yang sudah ada atau yang akan terjadi untuk memperoleh barang atau jasa. Biaya yang dikorbankan berguna untuk masa yang akan datang atau mempunyai manfaat lebih dari satu periode akuntansi yang diukur dalam satuan uang.

\section{Klasifikasi Biaya}

Klasifikasi biaya merupakan salah satu hal yang dapat membantu perusahaan untuk mencapai tujuannya. Klasifikasi biaya dikelompokkan berdasarkan informasi biaya yang disajikan. Klasifikasi biaya akan memberikan gambaran mengusulkan metode Activity Based Costing $(\mathrm{ABC})$, sebagai metode alternatif kepada pihak manajemen dalam menentukan iuran bagi penghuni apartemen. Metode ini diharapkan mampu mengukur biaya layanan fasilitas apartemen secara akurat dan dijadikan standar atau acuan dalam menentukan besarnya IPL.

informasi yang akurat kepada pihak manajemen. Klasifikasi biaya ini digunakan untuk memudahkan pencatatan biaya dan penyusunan laporan keuangan. Pencatatan klasifikasi biaya menurut (Mulyadi, 2015), yaitu "pencatatan dilakukan secara sistematis dan keseluruhan elemen biaya yang ada dalam golongan-

golongan tertentu dicatat lebih ringkas, untuk dapat memberikan informasi yang akurat dan penting". (Horngren, Charles T., 2015) mengemukakan pendapat mengenai klasifikasi biaya, sebagai berikut :

1. Klasifikasi biaya berdasarkan Terminology, diantaranya adalah:

a. Direct Cost, merupakan biaya yang dikaitkan dengan objek biaya dan dapat ditelusuri dengan cara yang ekonomis atau mudah.

b. Indirect Cost, merupakan biaya yang dikaitkan dengan objek biaya, namun tidak dapat ditelusuri dengan cara yang ekonomis atau tidak mudah.

2. Klasifikasi berdasarkan pola perilaku, diantaranya adalah:

a. Variable Cost, perubahan biaya yang terjadi sesuai dengan perubahan tingkat aktivitas yang terkait atau volume output yang dihasilkan.

b. Fixed Cost, tidak berubahnya biaya untuk periode waktu tertentu, meskipun ada perubahan besar pada aktivitas yang terkait atau volume output yang dihasilkan.

c. Cost Driver, sebuah variabel yang mempengaruhi biaya selama rentang waktu tertentu.

d. Relevant Range, aktivitas normal di mana ada hubungan spesifik antara level of activity dan biaya yang diberikan. Misalnya fixed cost hanya ditetapkan dalam kisaran yang relevan.

e. Unit Cost, membagi total cost berdasarkan number of units. 
3. Klasifikasi berdasarkan biaya produksi, diantaranya adalah:

a. Direct Material Cost, merupakan penggunaan seluruh biaya bahan baku (mentah, setengah jadi, dan barang jadi) terkait dari objek biaya dan dapat ditelusuri ke

b. objek biaya dengan cara yang ekonomis atau mudah.

c. Direct Manufacturing Labor, merupakan penggunaan seluruh biaya tenaga kerja dan dapat ditelusuri ke objek biaya dengan cara yang ekonomis atau mudah.

d. Indirect Manufacturing Cost, merupakan semua biaya yang dikaitkan dengan objek biaya namun tidak dapat ditelusuri dengan dengan cara ekonomis. Tipe biaya ini juga disebut sebagai manufacturing overhead costs atau factory overhead costs.

\section{Akuntansi Biaya}

Akuntansi biaya menurut (Mulyadi, 2015) adalah "proses pencatatan, penggolongan, peringkasan penyajian biaya, pembuatan dan penjualan produk atau jasa dengan cara-cara tertentu, serta penafsiran terhadapnya". Sama halnya dengan pengertian Akuntansi biaya yang dikemukakan Mulyadi, menurut oleh (Horngren, Charles T., 2015) akuntansi biaya adalah "proses mengukur, menganalisis, dan melaporkan informasi keuangan dan non-keuangan yang terkait biaya dengan menggunakan sumber daya dalam suatu organisasi. Akuntansi biaya menurut (Hansen, D. R., Mowen, M.M., \& Guan, 2015) adalah "mendesain biaya yang berhubungan dengan produk atau jasa yang memiliki keuntungan bagi manajemen".

Akuntansi keuangan (financial accounting) dapat melihat biaya-biaya yang dikeluarkan melalui perhitungan laba rugi dan neraca, sedangkan akuntansi biaya (Cost Accounting) dapat melihat lebih jauh tentang rincian total biaya dan biayabiaya aktual lainnya. Hansen, D. R., Mowen, M.M., \& Guan, (2015) menyatakan dengan akuntansi biaya membantu manajemen perusahaan untuk mengetahui dengan jelas beberapa hal, sebagai berikut:

1. Merencanakan tindakan biaya produksi di masa depan untuk mencapai tujuan tertentu

2. Memantau implementasi rencana pembiayaan yang telah ditetapkan

3. Struktur biaya untuk setiap jenis produk yang dihasilkan
4. Perbandingan biaya dan waktu untuk produk-produk yang dihasilkan

5. Pengaturan perkiraan-perkiraan untuk keperluan tender dan sebagainya

6. Memberikan alternatif biaya lainnya

Berdasarkan definisi diatas disimpulkan bahwa akuntansi biaya adalah proses pencatatan, penggolongan, penelusuran dan peringkasan biaya mulai dari pembuatan hingga penjualan barang atau jasa, serta menyajikan informasi berupa bentuk laporan biaya. Akuntansi biaya digunakan untuk berbagai macam tujuan baik pengendalian maupun pengambilan keputusan yang tepat bagi perusahaan

\section{Activity Based Costing (ABC)}

Activity Based Costing (ABC) menurut (Hansen, D. R., Mowen, M.M., \& Guan, 2015) merupakan "sebagai sumber utama informasi manajemen untuk menentukan aktivitas biaya yang terjadi". Pengertian lainnya Activity Based Costing (ABC) menurut (Horngren, Charles T., 2015) adalah suatu peristiwa, tugas, atau unit kerja dengan tujuan tertentu dan memperbaiki sistem penetapan biaya dengan mengidentifikasi aktivitas individu sebagai objek biaya. Activity Based Costing (ABC) menurut Mulyadi (2014) adalah "sistem informasi biaya yang berorientasi pada penyediaan informasi lengkap tentang aktivitas perusahaan untuk memungkinkan manajemen perusahaan melakukan pengolahan terhadap aktivitas tersebut. Sistem informasi ini menggunakan aktivitas sebagai basis pengurangan biaya dan penentuan secara akurat terhadap biaya produksi suatu produk". Hal ini ditujukan untuk mengarahkan seluruh aktivitas perusahaan ke dalam produk atau jasa, untuk memenuhi kepuasan kebutuhan pelanggan.

Berdasarkan penjelasan pengertian Activity Based Costing dari beberapa ahli diatas dapat disimpulkan bahwa Activity Based Costing adalah suatu metode perhitungan dimana biaya dan pembebanan produknya dilakukan dengan cara menelusuri biaya dari aktivitas perusahaan sampai menjadi produk/jasa. Metode $\mathrm{ABC}$ ini dilandasi oleh munculnya penyebab dan sumber dari biaya itu sendiri. Penerapan Activity Based Costing (ABC) menurut (Horngren, Charles T., 2015) menjelaskan bahwa menggunakan sistem ABC merupakan landasan dasar dalam perhitungan biaya yang efektif dan efisien. ABC memperbaiki setiap penetapan biaya yang kurang tepat dan menghasilkan keputusan strategi pembiayaan yang tepat. 
Sistem Iuran Pengelola (IPL) Apartemen

Sistem Iuran Pengelola Apartemen berguna untuk meningkatkan kualitas dan keberlangsungan apartemen itu sendiri. Iuran yang ditagih ke penghuni akan dicatat dalam akuntansi biaya. Akuntansi biaya digunakan untuk mengetahui penyebab utama biaya yang terjadi di suatu apartemen, memberikan informasi berupa laporan biaya yang akurat, memberi jaminan akuntabilitas dan transparansi penggunaan dana serta menghasilkan laporan biaya yang terkini (up to date), yang sangat berguna bagi pengambilan keputusan manajemen.

Laporan biaya yang berkaitan dengan aktivitas biaya di apartemen sangat beragam, dan banyak ahli yang mengemukakan pendapat yang berbedabeda. Salah satunya pendapat menurut Suharsaputra (2013), biaya di apartemen biasanya meliputi:

a. Direct cost dan indirect cost. Direct cost (biaya langsung) adalah biaya yang secara langsung dapat dirasakan dalam tempat tinggal hunian dan dapat secara langsung meningkatkan mutu hunian. Sedangkan biaya tidak langsung, meliputi biaya hidup, transportasi, dan biaya-biaya lainnya.

\section{METODE PENELITIAN}

Jenis penelitian yang digunakan adalah penelitian deskriptif. Penelitian deskriptif kuantitatif menurut Sugiyono (2014) adalah "sebagai suatu metode dalam meneliti status sekelompok manusia, suatu objek, suatu kondisi, suatu sistem pemikiran, ataupun suatu peristiwa dimasa sekarang dengan tujuan untuk membuat deskripsi, gambaran atau lukisan secara sistematis, faktual dan akurat mengenai fakta-fakta, sifat-sifat serta hubungan antar fenomena yang diselidiki”.

Data penelitian diperoleh peneliti dengan menggunakan metode observasi, wawancara, studi dokumentasi dan pustaka. Kerangka kerja yang digunakan, yaitu merancang metode ABC (Activity Based Costing) dalam unit pengelolaan iuran Apartemen Woodland Park Residence Tower Matoa dan dilanjutkan pada tahap perhitungan unit cost untuk biaya iuran yang tepat bagi hunian Apartemen Woodland Park Residence Tower Matoa.

\section{Fokus Penelitian}

Fokus penelitian sebagai sasaran dan arah dari b. Social cost dan private cost. Social cost merupakan biaya fasilitas publik, yaitu biaya apartemen yang harus dibayar oleh penghuni dan manfaatnya dirasakan secara bersama antar penghuni, sedangkan private cost adalah biaya yang dikeluarkan oleh penghuni yang manfaat dirasakan oleh masing-masing penghuni.

Biaya pelayanan/iuran menurut (Daryanto \& Setyobudi, 2014), harus ditetapkan standar biaya/tarif pelayanan termasuk rinciannya yang ditetapkan dalam proses pemberian pelayanan. Pengenaan biaya yang secara wajar dan terperinci serta tidak melanggar ketentuan yang berlaku. Begitu juga ketika adanya kenaikan tarif/biaya pelayanan diikuti dengan peningkatan kualitas pelayanan. Biaya pelayanan harus ditetapkan setransparansi mungkin. Kualitas apartemen bergantung pada biaya Iuran Pengelola (IPL) yang dikenakan ke penghuni serta profesionalisme-nya pengelola apartemen dalam mengatur keuangan. Biaya IPL bersifat maintenance fee, dimana fasilitas dipakai secara bersama-sama maka perhitungan biaya IPL dihitung berdasarkan luas semi gross unit apartemen.

penelitian ini adalah menggambarkan tentang Activity Based Costing sebagai metode dasar penentuan Iuran pengelola (IPL) apartemen yang nantinya akan dibandingkan dengan tarif IPL yang sudah berlaku di apartemen Woodland Park Residence Tower Matoa. Sampel penelitian ini terkhususkan pada Tower Matoa hal ini dikarnakan penjualan apartemen sudah habis terjual. Pada Tower Matoa memiliki 3 tipe hunian yang terdiri dari; tipe studio, tipe $1+1$ BR dan tipe 2 BR. Penelitian ini diketahui bahwa terdapat 18 kategori aktivitas biaya utama yang terkait pada IPL apartemen Woodland Park Residence Tower Matoa.

\section{Tahapan Penelitian}

Instrumen yang digunakan dalam penelitian ini adalah data keuangan dan non keuangan yang dirumuskan untuk mencapai tahapan penelitian dan analisis sebagai berikut:

1. Review data keuangan dan identifikasi proses bisnis

2. Menganalisis SWOT dengan tepat 
3. Identifikasi Cost Object, Direct Labor, Direct Material dan Overhead Cost

4. Menghitung aktivitas biaya yang terjadi:

-Perhitungan direct material

-Perhitungan direct labor

-Perhitungan overhead cost

5. Perhitungan Iuran Pengelola (IPL) menggunakan metode tradisional

\section{HASIL DAN PEMBAHASAN}

Berdasarkan penelitian yang dilakukan oleh peneliti di apartemen Woodland Park Residence Tower Matoa, diperoleh keterangan bahwa dalam menentukan tarif IPL, apartemen tidak memiliki

\section{Laporan Biaya}

6. Perhitungan Iuran Pengelola (IPL) menggunakan metode $\mathrm{ABC}$

7. Perbandingan perhitungan biaya menggunakan metode $\mathrm{ABC}$, metode tradisional dan tarif berlaku

8. Perbandingan perhitungan Iuran Pengelola (IPL) apartemen menggunakan metode $\mathrm{ABC}$, metode tradisional dan tarif berlaku

metode dalam perhitungan biaya. Sehingga dibutuhkan suatu metode yang dapat mendeteksi biaya secara langsung dan tidak langsung.

Tabel 1.

Total Direct Material Pada Bulan Juni

\begin{tabular}{|c|c|c|}
\hline No & Aktivitas & Total Biaya (Rp) \\
\hline 1 & Pengadaan Bahan Pembersih & 3.843 .000 \\
\hline 2 & Pengadaan Alat Tulis Kantor & 1.063 .500 \\
\hline \multicolumn{2}{|c|}{ Total Direct Material } & Rp 4.906.500 \\
\hline
\end{tabular}

Sumber: data diolah 2020

Tabel 2.

Total Direct Labor Pada Bulan Juni

\begin{tabular}{|c|c|c|}
\hline No & Aktivitas & Total Biaya (Rp) \\
\hline 1 & Gaji Petugas administrasi & 17.900 .000 \\
\hline 2 & Gaji Petugas Keamanan atau Satpam & 34.600 .000 \\
\hline 3 & Gaji Petugas Teknisi & 26.300 .000 \\
\hline 4 & Gaji Petugas Kebersihan/Cleaning Service & 38.400 .000 \\
\hline 5 & Gaji Petugas Customer Service & $\underline{22.100 .000}$ \\
\hline \multicolumn{2}{|c|}{ Total Direct Labor } & $\mathbf{R p ~ 1 3 9 . 3 0 0 . 0 0 0}$ \\
\hline
\end{tabular}

Sumber: data diolah 2020

Tabel 3.

Penetuan Tarif Per Unit Cost Driver

\begin{tabular}{|c|c|c|c|c|}
\hline No & $\begin{array}{l}\text { Aktivitas } \\
\text { Biaya }\end{array}$ & Jumlah & Cost Driver & $\begin{array}{l}\text { Tarif Per } \\
\text { Unit }\end{array}$ \\
\hline 1 & $\begin{array}{l}\text { Pemeliharaan } \\
\text { Lahan Parkir } \\
\text { Biaya: } \\
\text {-Aktivitas } \\
\text { Petugas } \\
\text { Kebersihan }\end{array}$ & $\begin{array}{l}\mathrm{Rp} \\
22.000 .000\end{array}$ & $\begin{array}{l}1.863 \mathrm{M}^{2} \\
1.863 \mathrm{M}^{2}\end{array}$ & $\begin{array}{l}\text { Rp } 11.916 \\
\text { Rp } 18.572\end{array}$ \\
\hline
\end{tabular}




\begin{tabular}{|c|c|c|c|c|}
\hline & $\begin{array}{l}\text {-Aktivitas } \\
\text { Petugas } \\
\text { Keamanan } \\
\text {-Aktivitas } \\
\text { Listrik }\end{array}$ & $\begin{array}{l}\mathrm{Rp} \\
34.600 .000 \\
\mathrm{Rp} \\
8.000 .000\end{array}$ & $1.200 \mathrm{KWH}$ & $\operatorname{Rp} 6.666$ \\
\hline 2 & $\begin{array}{l}\text { Pemeliharaan } \\
\text { Kebersihan } \\
\text { Apartemen } \\
\text { Biaya: } \\
\text {-Aktivitas } \\
\text { Petugas } \\
\text { Kebersihan } \\
\text {-Pengadaan } \\
\text { Bahan } \\
\text { Pembersih } \\
\text {-Aktivitas } \\
\text { Listrik Alat } \\
\text { Kebersihan }\end{array}$ & $\begin{array}{l}\mathrm{Rp} \\
38.400 .000 \\
\mathrm{Rp} \\
3.843 .000 \\
\mathrm{Rp} \\
5.000 .000\end{array}$ & $\begin{array}{l}1.800 \mathrm{M}^{2} \\
1.800 \mathrm{M}^{2} \\
60 \mathrm{jam}\end{array}$ & $\begin{array}{l}\operatorname{Rp} 21.333 \\
\operatorname{Rp} 2.135 \\
\operatorname{Rp} 83.333\end{array}$ \\
\hline 3 & $\begin{array}{l}\text { Pemeliharaan } \\
\text { Tempat Gym } \\
\text { Biaya: } \\
\text {-Aktivitas } \\
\text { Petugas } \\
\text { Teknisi } \\
\text {-Aktivitas } \\
\text { Petugas } \\
\text { Kebersihan } \\
\text {-Aktivitas } \\
\text { Listrik }\end{array}$ & $\begin{array}{l}\mathrm{Rp} \\
4.200 .000 \\
\mathrm{Rp} \\
3.700 .000 \\
\mathrm{Rp} \\
3.000 .000\end{array}$ & $\begin{array}{l}50 \mathrm{M}^{2} \\
50 \mathrm{M}^{2} \\
50 \mathrm{M}^{2}\end{array}$ & $\begin{array}{l}\operatorname{Rp} 84.000 \\
\operatorname{Rp} 74.000 \\
\operatorname{Rp} 60.000\end{array}$ \\
\hline 4 & $\begin{array}{l}\text { Pemeliharaan } \\
\text { Kolam Renang } \\
\text { Biaya: } \\
\text {-Aktivitas } \\
\text { Petugas } \\
\text { Kebersihan }\end{array}$ & $\begin{array}{l}\mathrm{Rp} \\
38.400 .000\end{array}$ & $1.250 \mathrm{M}^{2}$ & Rp 26.640 \\
\hline 5 & $\begin{array}{l}\text { Pemeliharaan } \\
\text { Taman } \\
\text { Biaya: } \\
\text {-Aktivitas } \\
\text { Petugas } \\
\text { Kebersihan }\end{array}$ & $\begin{array}{l}\mathrm{Rp} \\
22.200 .000\end{array}$ & $90 \mathrm{M}^{2}$ & $\begin{array}{l}\mathrm{Rp} \\
246.666\end{array}$ \\
\hline 6 & $\begin{array}{l}\text { Pemeliharaan } \\
\text { Lift }\end{array}$ & $\begin{array}{l}\mathrm{Rp} \\
1.000 .000\end{array}$ & 18 lantai & Rp 55.555 \\
\hline 7 & $\begin{array}{l}\text { Pemeliharaan } \\
\text { Jogging track } \\
\text {-Aktivitas } \\
\text { Petugas } \\
\text { Kebersihan }\end{array}$ & $\begin{array}{l}\mathrm{Rp} \\
7.400 .000\end{array}$ & $90 \mathrm{M}^{2}$ & Rp 82.222 \\
\hline 8 & $\begin{array}{l}\text { Pemeliharaan } \\
\text { Water } \\
\text { Treatment }\end{array}$ & & & \\
\hline
\end{tabular}




\begin{tabular}{|c|c|c|c|c|}
\hline & $\begin{array}{l}\text { Plant (WTP) } \\
\text { Biaya: } \\
\text {-Aktivitas } \\
\text { Petugas } \\
\text { Teknisi }\end{array}$ & $\begin{array}{l}\mathrm{Rp} \\
26.300 .000\end{array}$ & $6.030 \mathrm{KWH}$ & Rp 30.534 \\
\hline 9 & $\begin{array}{l}\text { Pemeliharaan } \\
\text { Children } \\
\text { Playground } \\
\text { Biaya: } \\
\text { - Aktivitas } \\
\text { Petugas } \\
\text { Kebersihan }\end{array}$ & $\begin{array}{l}\mathrm{Rp} \\
3.700 .000\end{array}$ & $100 \mathrm{M}^{2}$ & Rp 37.000 \\
\hline 10 & $\begin{array}{l}\text { Depresiasi } \\
\text { Furniture } \\
\text { Penghuni } \\
\text { Biaya: } \\
\text {-Total Harga } \\
\text { Perolehan } \\
\text { Furniture }\end{array}$ & $\begin{array}{l}\mathrm{Rp} \\
16.775 .000\end{array}$ & 61 unit & $\begin{array}{l}\mathrm{Rp} \\
275.000\end{array}$ \\
\hline 11 & $\begin{array}{l}\text { Penyediaan } \\
\text { Telepon } \\
\text { Intelcom } \\
\text { Biaya: } \\
\text {-Penyediaan } \\
\text { Pulsa Telepon }\end{array}$ & $\begin{array}{l}\mathrm{Rp} \\
15.825 .000\end{array}$ & 211 unit & $\mathrm{Rp} 75.000$ \\
\hline
\end{tabular}

Sumber: data diolah 2020

Tabel 4.

Total Overhead Pada Bulan Juni

\begin{tabular}{|l|r|r|r|}
\hline Aktivitas & $\begin{array}{l}\text { Tarif Per Cost } \\
\text { Driver (Rp) }\end{array}$ & $\begin{array}{l}\text { Driver yang } \\
\text { Digunakan }\end{array}$ & $\begin{array}{l}\text { Total Overhead } \\
\text { (Rp) }\end{array}$ \\
\hline Pemeliharaan Lahan Parkir: & 11.916 & $600 \mathrm{~m} 2$ & 7.149 .600 \\
-Kebersihan & 18.572 & $200 \mathrm{~m} 2$ & 3.714 .400 \\
-Keamanan & 6.666 & $200 \mathrm{kwh}$ & 1.333 .200 \\
-Listrik & & & \\
\hline Pemeliharaan Kebersihan & 21.333 & $900 \mathrm{~m} 2$ & 19.199 .700 \\
Apartemen: & 2.135 & $900 \mathrm{~m} 2$ & 1.921 .500 \\
-Kebersihan & 83.333 & $60 \mathrm{jam}$ & 4.999 .980 \\
-Bahan Pembersih & & & 10.900 .000 \\
Listrik & 84.000 & $50 \mathrm{~m} 2$ & 4.200 .000 \\
\hline Pemeliharaan Tempat Gym: & 74.000 & $50 \mathrm{~m} 2$ & 3.700 .000 \\
-Teknisi & 60.000 & $50 \mathrm{~m} 2$ & 3.000 .000 \\
-Kebersihan & & & \\
-Listrik & 26.640 & $1.000 \mathrm{~m} 2$ & 26.640 .000 \\
\hline Pemeliharaan Kolam Renang: & & & \\
-Kebersihan & 246.666 & $90 \mathrm{~m} 2$ & 22.199 .940 \\
\hline Pemeliharaan Taman: & & & \\
-Kebersihan & & & \\
\hline Pemeliharaan Lift: & & & \\
\hline
\end{tabular}




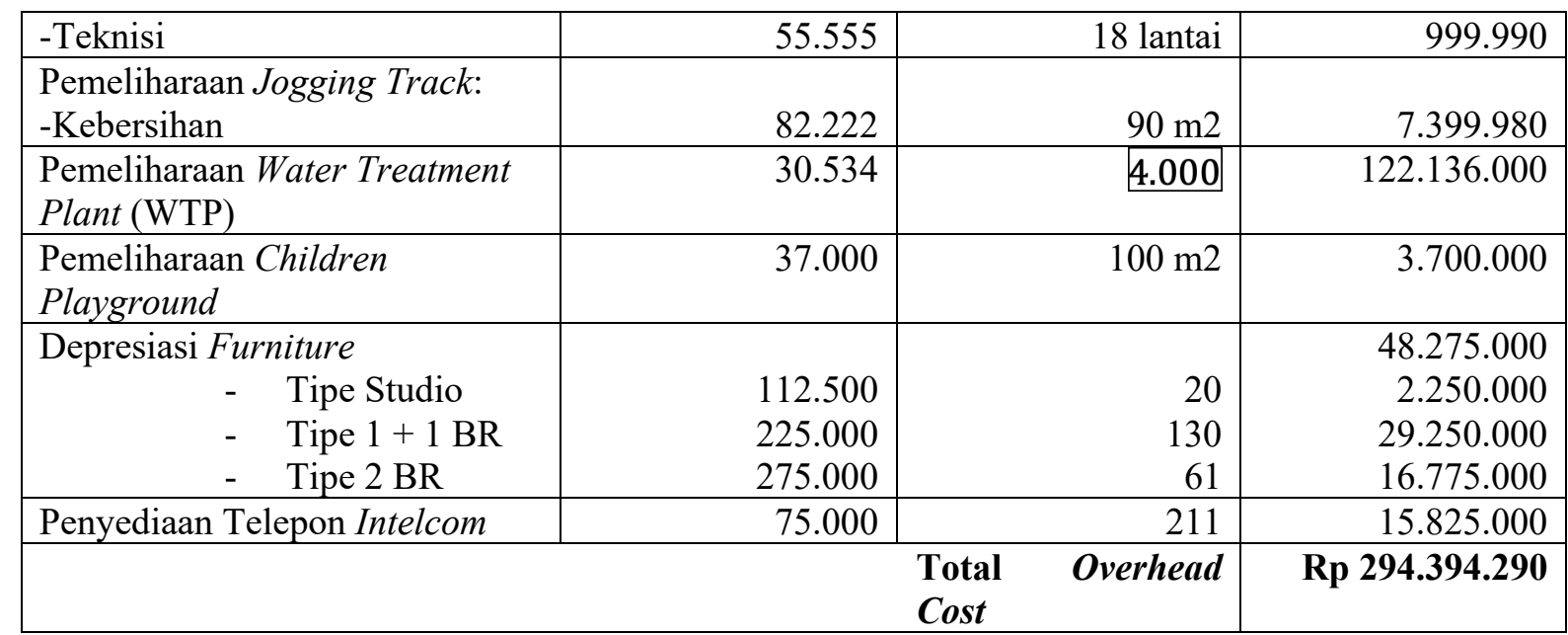

\begin{tabular}{|r|r|r|r|r|}
\hline & DM & DL & OH & \\
\hline Total & 4.906 .500 & 139.300 .000 & 294.394 .290 & 438.598 .790 \\
\hline \multicolumn{4}{|c|}{$\begin{array}{l}\text { Biaya 3 tipe } \\
\text { hunian }\end{array}$} & Rp 2.078.667 \\
\hline
\end{tabular}

Sumber: data diolah 2020

IPL Per Bulan Menggunakan Metode ABC

Iuran per bulan $=\frac{(\text { Biaya } 3 \text { Tipe Hunian }(\text { Rp }) \times \text { Proporsi }(\%))}{\text { Jumlah Unit Hunian }} \times$ Luas unit Hunian $\left(m^{2}\right)$

Sumber: diolah dari data primer 2020

Tipe Studio

Iuran per bulan $=\frac{(R p 2.078 .667 \times 9 \%)}{20 \text { unit }} \times 28,06 \mathrm{~m}^{2}$

Iuran per bulan $=R p 262.473$

Tipe 1+ 1 BR

Iuran per bulan $=\frac{(R p 2.078 .667 \times 62 \%)}{130 \text { unit }} \times 39.58 \mathrm{~m}^{2}$

Iuran per bulan $=R p 392.382$

Tipe 2 BR

Iuran per bulan $=\frac{(R p 2.078 .667 \times 29 \%)}{61 \text { unit }} \times 55.60 \mathrm{~m}^{2}$

Iuran per bulan $=R p 549.450$

Dari perhitungan diatas dapat dijelaskan yang sulit ditelusuri, dihitung dengan cara membagi bahwa biaya yang dikeluarkan untuk apartemen antara jumlah aktivitas dengan cost driver, dimana Woodland Park Residence di Tower Matoa adalah Direct Material (DM) sebesar Rp 4,906,500 sedangkan Direct Labor (DL) sebesar Rp 139,300,000 dan Overhead (OH) sebesar Rp 294.394.290. Perhitungan direct material, yaitu pengadaan barang habis pakai yang dihitung dari perkalian antara jumlah barang dengan harga per unit. Perhitungan direct labor, yaitu gaji masingmasing pegawai dihitung dari gaji pokok ditambah tanggungan biaya transportasi (jika ada), serta dikali dengan banyaknya jumlah pekerja. Begitu juga dengan overhead cost, yaitu seluruh aktivitas driver dipilih yang paling relevan dan sesuai dengan pembiayaan apartemen.

Dengan menggunakan rumus yang terlah disajikan diatas dalam perhitungan IPL menggunakan metode ABC. Tipe hunian studio dikenakan tarif IPL sebesar Rp 262.473 per bulan. Kemudian pada tipe $1+1$ BR dikenakan tarif IPL sebesar Rp 392.382 per bulan. Terakhir pada tipe hunian 2 BR dikenakan tarif IPL sebesar Rp 549.450 per bulan. Tarif IPL ini wajib dibayar masing-masing penghuni setiap 
bulannya.

Perbandingan Metode Tradisional, ABC dan Tarif Berlaku

\begin{tabular}{|l|r|r|r|r|r|}
\hline $\begin{array}{l}\text { Tipe } \\
\text { Hunian }\end{array}$ & Tradisional & ABC & $\begin{array}{l}\text { Tarif } \\
\text { Berlaku }\end{array}$ & $\begin{array}{l}\text { Selisih Tarif } \\
\text { Berlaku-ABC }\end{array}$ & $\begin{array}{l}\text { Selisih } \\
\text { Tradisional- } \\
\text { ABC }\end{array}$ \\
\hline Studio & 257.478 & 262.437 & 516.200 & 253.763 & 4.959 \\
\hline $1+1$ BR & 384.912 & 392.382 & 791.600 & 399.218 & 7.470 \\
\hline 2 BR & 538.990 & 549.450 & 1.112 .000 & 562.550 & 9.460 \\
\hline
\end{tabular}

Sumber: data diolah 2020

Pada tabel diatas diketahui bahwa menggunakan metode $\mathrm{ABC}$ menghasilkan iuran per bulan yang berbeda-beda, yaitu tipe studio sebesar Rp 262.437 per bulan, $1+1$ BR sebesar Rp 392.382 per bulan dan tipe 2 BR sebesar Rp 549.450 per bulan. Sedangkan metode tradisional memiliki iuran yang berbeda juga pada masingmasing tipe, yaitu tipe studio sebesar Rp 257.478 per bulan, $1+1$ BR sebesar Rp 384.912 per bulan dan tipe 2 BR sebesar Rp 538.990 per bulan.

Jadi, jika IPL menggunakan metode $\mathrm{ABC}$ dibanding dengan tarif yang berlaku saat ini pada studio maka, terjadi selisih sebesar Rp 253.763 (overcost). Kemudian pada tipe $1+1$ BR terjadi selisih sebesar Rp 399.218 (overcost). Terakhir pada tipe 2 BR dibanding dengan tarif berlaku maka terjadi selisih sebesar Rp 562.550 (overcost). Selisih antara tarif berlaku dengan metode $\mathrm{ABC}$

terjadi overcost hal ini disababkan karena biaya yang termasuk di dalam tarif berlaku terdapat beberapa aktivitas yang tidak bernilai tambah, di mana seharusnya tidak termasuk ke dalam tarif IPL sehingga menyebabkan terlalu banyak biaya yang harus dibayar penghuni, contohnya seperti; biaya pembelian furniture, biaya pemasaran, listrik kantor, seragam pegawai, koordinasi RT/RW, dan penyewaan gondola.

Penagihan IPL dengan tarif yang berlaku saat ini lebih besar dari pada metode $\mathrm{ABC}$ dan metode tradisional diharapkan tidak terlalu membebankan pihak penghuni. Diharapkan juga pihak manajemen dapat mempertimbangkan biaya IPL dengan memperhatikan biaya IPL dari kompetitor yang sejenis serta menetapkan IPL khusus untuk memenuhi pelayanan penghuni. Hal ini dilakukan untuk meningkatkan kepuasan bagi penghuni.

\section{KESIMPULAN DAN SARAN}

\section{Kesimpulan}

1. Dari hasil analisa aktivitas yang ada pada Apartemen Woodland Park Residence Tower Matoa dibuat deskripsi aktivitas yang terdiri dari 18 aktivitas utama. Hasil perhitungan metode $\mathrm{ABC}$ telah mengidentifikasikan aktivitas-aktivitas di 3 tipe apartemen Tower Matoa, dengan menghasilkan nilai total

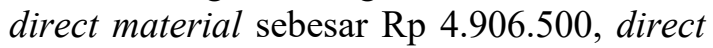
labor sebesar Rp 139.300.000 dan overhead cost sebesar Rp 294.394.290 selama bulan juni. Kemudian hasil perhitungan besaran Iuran Pengelola (IPL) apartemen pada 3 tipe hunian dengan menggunakan metode $\mathrm{ABC}$, diketahui bahwa Iuran Pengelola (IPL) per bulan tipe studio sebesar Rp 262.437 per bulan, 1 + 1 BR sebesar Rp 392.382 per bulan dan tipe 2 BR sebesar Rp 549.450 per bulan.

2. Terdapat perbedaan antara Iuran Pengelola (IPL) apartemen pada 3 tipe hunian

menggunakan metode ABC, metode tradisional dan yang tarif berlaku saat ini di Apartemen Woodland Park Residence Tower Matoa. Untuk Iuran Pengelola (IPL) menggunakan tarif berlaku saat ini per bulan tipe studio sebesar Rp 516.200, sedangkan tipe 1+1 BR per bulan sebesar Rp 791.600 dan tipe 2 BR per bulan sebesar Rp 1.112.000. Dengan demikian telah terjadi overcosted pada tipe studio sebesar $\mathrm{Rp}$ 253.763. Untuk Iuran pengelola (IPL) tipe 1 +1 BR terjadi overcost sebesar Rp 399.218. Untuk Iuran pengelola (IPL) tipe 2 BR terjadi overcost sebesar Rp 562.550. Untuk Iuran Pengelola (IPL) menggunakan metode tradisional per bulan tipe studio sebesar Rp 257.478, sedangkan tipe $1+1$ BR per bulan sebesar Rp 384.912 dan tipe 2 BR per bulan sebesar Rp 538.990.

Saran 
1. Penagihan IPL dengan tarif yang berlaku saat ini lebih besar dari pada metode $\mathrm{ABC}$ dan metode tradisional diharapkan tidak terlalu membebankan pihak penghuni. Diharapkan juga pihak manajemen dapat mempertimbangkan biaya IPL dengan memperhatikan biaya IPL dari kompetitor yang sejenis. Hal ini dilakukan untuk meningkatkan kepuasan bagi penghuni.

2. Jika pihak manajemen tertarik menggunakan metode $\mathrm{ABC}$ dalam menentukan tarif IPL maka dibutuhkan persiapan yang benar dalam melusuri biaya-biaya yang tepat ke

\section{DAFTAR PUSTAKA}

Akmal, I. 2007. Menata Apartemen. Jakarta: PT. Gramedia Pustaka Utama.

Daryanto \& Setyobudi, I. (2014). Konsumen dan Pelayanan Prima. : Gava Media.

Fattah, Nanang. 2012. Standar Pembiayaan Pendidikan. Bandung: PT Remaja Rosdakarya.

Hansen, D. R., Mowen, M.M., \& Guan, L. (2015). Cost Management (Accounting \& Control). Cengage Learning. masing-masing aktivitas. Dengan menggunakan metode ABC akan menghasilkan perhitungan akurat.

3. Diharapkan saat menentukan tarif IPL biayabiaya yang termasuk ke dalam IPL merupakan biaya fasilitas yang khusus untuk melayani penghuni. Serta tidak memasukan biaya-biaya yang tidak berhubungan langsung dengan pemberian pelayanan penghuni karena bisa saja memberatkan penghuni dalam memenuhi kewajibannya untuk membayar IPL yang nantinya malah sulit untuk ditagih.
Horngren, Charles T., dkk. (2015). Cost Accounting: A Managerial Emphasis, Global Edition (15th ed.). Pearson.

Kotler, Philip and Kevin Lane Keller, 2016. Marketing Management, $15^{\text {th }}$ Edition. Pearson

Mulyadi. (2015). Akuntansi Biaya (5 (Ed.)). Sekolah Tinggi Ilmu Manajemen. 